\title{
KEUNIKAN UJARAN ANAK USIA DINI STUDI KASUS DI KB/TK ATTOHIRIN SUKODONO USIA 3-6 TAHUN
}

\author{
Nur Hayati, Agung Pramujiono, Ira EkoRetnosari \\ (Program Studi Pendidikan Bahasa dan Sastra Indonesia, Fakultas Keguruan dan Ilmu \\ Pendidikan, Universitas PGRI Adibuana Surabaya) \\ Hayati.NH116@gmail.com, agungpramujiono.unipasby@gmail.com, \\ ira_eko_80@yahoo.com
}

\begin{abstract}
ABSTRAK
Penelitian ini dilatarbelakangi oleh kenyataan bahwa anak-anak yang berusia 3-6 tahun sangat unik memiliki cadel saat berbicara, dan mereka juga menciptakan bentuk-bentuk kata baru yang hanya dipahami oleh dirinya sendiri dan orang-orang terdekatnya. mereka. Ciptaan semacam ini dipengaruhi oleh bahasa yang digunakan oleh ibu dari anak-anak tersebut yang juga bisa disebut sebagai jargon khusus yang digunakan olehnya. Keunikan pernyataan dalam penelitian ini adalah pada kekhasan masing-masing bahasa di dunia. Keistimewaan itu meliputi tata bunyi suatu bahasa, pembentukan kata suatu bahasa, pembentukan kalimat bahasa, dan lain-lain. Dalam tata bunyi, anakanak yang berusia 3-6 tahun, sering berbicara dengan gaya bahasanya sendiri yang terkadang juga jargon keluarga anak-anak itu sendiri. Anak usia dini adalah anak yang berusia $0-8$ tahun. KB/TK Attohirin merupakan salah satu Lembaga Keislaman yang diselenggarakan oleh kepala sekolah yaitu $\mathrm{Hj}$. Umi Khaddah dan H. Sukarjo, di bawah Dinas Pendidikan Sidoarjo dan PGRI, bertempat di Desa Peterongan, Masangan Kulon RT18, RW06, Kecamatan Sukodono, Kabupaten Sidorjo. Objek penelitian ini adalah keunikan siswa pada KB/TK Attohirin yang berusia 3-6 tahun yang terdiri dari 2 putra berusia 3-4 tahun dan 1 putri berusia 5 tahun. Penelitian ini dilakukan di KB/TK Attohirin Desa Peterongan, Masangan Kulon RT18, RW06, Kecamatan Sukodono, Kabupaten Sidoarjo. Metode yang digunakan dalam penelitian ini adalah metode Cakap dibantu dengan menggunakan teknik Cakap Semuka, Teknik Perekaman, dan Teknik Catat, penelitian ini menggunakan metode agih. Berdasarkan hasil penelitian, disimpulkan bahwa huruf yang tidak dapat diucapkan oleh objek penelitian adalah 'r, g, dan k'. Meskipun demikian, objek dapat dengan jelas menyebutkan huruf-huruf tersebut, tetapi ketika huruf-huruf tersebut diucapkan dalam sebuah kata atau kalimat, bunyi huruf tersebut tidak diucapkan dengan jelas atau bahkan berubah.
\end{abstract}

Kata Kunci: Keunikan Bicara, Anak Usia Dini, Usia 3-6 tahun.

\section{PENDAHULUAN}

Keunikan ujaran adalah setiap bahasa mempunyai ciri khas yang spesifik tidak dimiliki oleh bahasa yang lain. Ciri khas tersebut dapat menyangkut sistem bunyi, sistem pembentukan kata, sistem pembentukan kalimat dan sistem lainnya. Dalam sistem bunyi misalnya, anak usia 3-6 tahun cenderung mengucapkan kata dengan bahasanya sendiri atau bahasa yang biasanya digunakan dalam keluarga, yaitu berkata pelat atau menciptakan kata-kata kreasi. 
Anak usia dini usia 3-6 tahun sangat unik yaitu berkata pelat dan menciptakan kata-kata kreasi yang hanya dimengerti oleh anak tersebut dan orang dekat di sekitarnya. Contoh kata unik yang diucapkan (Bu Gulu atu mau loh matan itan endok yang artinya Bu Guru aku tadi makan ikan telor/endok (dalam bahasa Jawa), ada juga yang berkata dengan bahasanya sendiri, contoh (ndot bitin yang artinya telur dadar), dan terpengaruh besar oleh bahasa ibu. Akan tetapi, kata-kata yang diujarkan tersebut ejaan yang salah, seperti berkata pelat tersebut. Bahasa ibu sangat dominan, karena waktu untuk berbicara dengan ibu lebih banyak daripada waktu berbicara pendidik dengan anak.

Anak usia dini adalah anak berusia 0-8 tahun. Anak usia dini berada pada tahap pertumbuhan dan perkembangan baik fisik maupun mental yang sangat pesat (Slamet, 2005:5). Anak usia dini sangat sensitif terhadap apa yang terjadi di lingkungannya. Oleh sebab itu, anak usia dini sering disebut dengan masa keemasan atau golden age. Karena itu, pendidikan pada masa ini merupakan pendidikan yang sangat fundamental dan sangat menentukan perkembangan anak selanjutnya. Apabila anak mendapatkan stimulus yang baik, seluruh aspek perkembangan anak akan berkembang secara optimal.

Salah satu potensi yang harus dikembangkan pada anak usia dini adalah kemampuan bahasa. Menurut Santrock (2007: 353), bahasa adalah suatu bentuk komunikasi entah itu lisan, tertulis atau isyarat yang berdasarkan pada suatu sistem dari simbol-simbol. Bahasa terdiri dari kata-kata yang digunakan oleh masyarakat beserta aturan-aturan untuk menyusun berbagai variasi mengkombinasikannya.

Latifah (2008) mengungkapkan bahwa melalui bahasa, seorang anak mampu menyampaikan keinginan dan pendapat serta perilaku, baik secara langsung maupun tidak langsung. Dengan demikian, bahasa memiliki peranan penting dalam aktivitas anak. Melalui bahasa, anak dapat berkomunikasi, berinteraksi dan mengekspresikan emosi yang dirasakannya. Menurut Santrock (2002), bahasa adalah suatu sistem simbol berkomunikasi dengan orang lain.

KB/TK Attohirin adalah salah satu nama Yayasan Pendidikan Islam yang dikelolah oleh ketua Hj.Umi Khaddah dan H.Sukardjo, dibawah naungan Dinas Pendidikan Sidoarjo dan PGRI. Menerima peserta didik usia dini mulai usia 26 tahun. Berada di dusun Peterongan, desa Masangan Kulon RT18, RW06 kecamatan Sukodono kabupaten Sidoarjo.

Dengan terpengaruhnya bahasa anak oleh bahasa ibu, sebagai pendidik sangat tertarik untuk membenarkan bahasa anak usia dini tersebut. Akan tetapi, itu tidak mudah dilakukan karena bahasa ibu sangat dominan, karena waktu untuk berbicara dengan ibu lebih banyak daripada waktu berbicara pendidik dengan anak dan itu sangaat banyak pengaruhnya terhadap penggunaan bahasa anak di lingkungan sekitar.

\section{METODE PENELITIAN}

Penelitian ini merupakan penelitian deskriptif-kualitatif. Fokusnya adalah penggambaran secara menyeluruh tentang bentuk ungkapan ujaran anak usia dini. Penelitian yang menghasilkan data deskriptif berupa kata-kata tertulis 
atau lisan dari orang-orang dan perilaku yang dapat diamati. Penelitian ini disebut penelitian kualitatif karena merupakan penelitian yang tidak mengadakan perhitungan. Objek yang digunakan dalam penelitian ini adalah keunikan ujaran anak usia dini di KB/TK Attohirin. Subjek penelitian ini adalah peserta didik di KB/TK Attohirin usia 3-6 tahun sebanyak 3 anak yaitu, 2 anak laki-laki berumur 3-4 tahun di Kelompok Bermain dan 1 anak perempuan berumur 5 tahun di TK A1, ketiga anak tersebut adalah anak yang nomal dan bukan termasuk anak yang ABK (Anak Berkebutuhan Khusus) penelitian ini dilakukan di $\mathrm{KB} / \mathrm{TK}$ Attohirin dusun Peterongan, desa Masangan kulon RT18, RW06, Kecamatan Sukodono, Kabupten Sidoarjo. Data dikumpulkan dengan metode cakap, yaitu metode penyediaan data dengan melakukan percakapan antara peneliti dan informan.

Untuk teknik pengumpulan data dilakukan sejumlah tahapan. Tahapan-tahapan yang dimaksud adalah:

1. menyiapkan alat-alat yang digunakan dalam proses pengumpulan data.

2. wawancara dengan peserta didik tanpa harus diketahui oleh anak, karena jika merekam pembicaraan anak dan diketahui oleh anak kata-kata yang diucapkan tidak seperti biasanya.

3. wawancara dengan orang tua peserta didik, bagaimanakah bahasa yang digunakan dalam sehari-hari di rumah.

4. transkripsi data dari bahasa lisan ke dalam bahasa tulis dan mencatat data tertulis.
Teknik analisis data dalam menganalisis data digunakan metode agih. Metode agih adalah metode analisis bahasa dengan alat penentu yang berasal dari bahasa itu sendiri (Sudaryanto, 1993:13; Mahsun, 2005:120). Metode agih digunakan untuk mengetahui bentuk ujaran anak.

\section{HASIL PENELITIAN}

Dari hasil penelitan yang dilakukan di KB/TK Attohirin Objek penelitian keunikan ujaran anak usia dini di KB/TK Attohirin. Dan subjek penelitian ini adalah peserta didik di KB/TK Attohirin usia 3-6 tahun sebanyak 3 anak yaitu, 2 anak laki-laki berumur 3-4 tahun di Kelompok Bermain dan 1 anak perempuan berumur 5 tahun di TK A1, ketiga anak tersebut adalah anak yang nomal dan bukan termasuk anak yang ABK (Anak Berkebutuhan Khusus) berikut hasilnya:

\section{Widya}

Dari segi fonologi, Widya yang berumur 5 tahun sudah mampu untuk berujar, namun ada beberapa huruf yang tak mampu untuk dilafalkannya. Contohnya seperti huruf g, r, k, c, dll. Sebenarnya ia bisa melafakalnya tetapi pada polapola tertentu ia kesulitan untuk melafalkan huruf-huruf tersebut.

\section{Perubahan huruf ' $r$ ' menjadi ' $l$ '} "Guru : Bagus tah?

Widya : Iyo lek, atu atu yo dini trus ambek dini atu.

Guru : Iya tah?

Widya : Iyoo,onok monyet balang yo.

Widya : Lek bunda Lini?

Guru : Bunda Rini ikut.

Widya : A tohilin.

Guru : Kenapa kok gak maem, ibu masak apa? 
Widya : Macak sambel ambek endot, ambek sayulan bayem. Guru : Ayahnya Widya kerja dimana?

Widya : Kelja di ucian.

Guru : Beli es cream, bawa uang berapa?

Widya : Dua libu, tapi dek tas.” (25/10/2016)

Bunyi-bunyi yang diucapkan oleh Widya sejak umur 5 tahun akan dilihat sebagai bagian dari pemerolehan bahasa. Pada umur 5 tahun, Widya telah banyak memperoleh dan memproduksi berbagai fonem yang dapat membedakan arti kata-kata yang diucapkannya. Hanya saja dalam mengungkapkan kata-kata ini pada umur 5 tahun, kemampuan fonologi Widya baru pada bunyi-bunyi konsonan seperti /r/, /l/, pada kata 'lek' 'rek' dalam bahasa jawa 'sayulan' (sayuran). Kata-kata ini sering sekali diucapkan oleh Widya.

Kata-kata tersebut diucapkan dalam situasi di sekolah misalnya ketika diajak berbicara. Fonem ' $r$ ' muncul sekali-sekali dan tidak sesering munculnva fonem ' 1 '. Ia tidak bisa melafalkan huruf ' $r$ ' karena mungkin huruf ' $r$ ' tersebut sulit untuk diucapkan dan makhorijul huruf ' 1 ' berdekatan dengan ' $r$ ' maka dari itu ia memilih melafalkannya dengan huruf ' $l$ '. Karena dalam pengucapan ' $r$ ' menjadi ' 1 ' Widya yang pelat lebih gampang menggunakan huruf 1 .

\section{Perubahan huruf ' $g$ ' menjadi}

'd'

"Widya : Dini loh.

Guru : Bagus tah?

Widya : Iyo lek, atu atu yo dini trus ambek dini atu.

Guru : Ohh, mau jadi bunda Nur.

Widya : Endak, bunda Indah.

Guru : Ada apa?
Widya : Monyet dodet-dodet, atu

loh dak punya gitu.

Guru : Bunda Sofi ikut.

Widya : Ndak ditu loh."

(25/10/2016)

Begitu juga pada kata 'gini' menjadi 'dini', 'enggak' menjadi 'endak', 'gitu' menjadi 'ditu', 'minggu' menjadi 'mindu' seperti yang terdapat pada kutipan percakapan di atas konsonan velar ' $g$ ' dan ' $d$ ' belum pernah terdengar kecuali ' $g$ ' pada akhir, misalnya pada kata 'sedang'.

Pada awal kata, konsonan ' $\mathrm{g}$ ' tidak terdengar seperti pada kata 'dak' (gak), 'dini' (gini), akan tetapi pada tengah kata juga tidak terdengar seperti pada kata 'mindu' (minggu) Sementara itu konsonan 'd' sering sekali terdengar. Misalnya pada kata mau jadi bunda Nur, konsonan 'd' pada kata 'jadi' dan 'bunda'.

\section{Perubahan huruf ' $k$ ' menjadi} ' $t$ '

"Widya : Yo atu, atu mau jadi bunda Nur.

Guru : Ohh, mau jadi bunda Nur.

Widya : Iti piye seh bunda,piye?

Guru : Peneliti membantu untuk memasangkan bros ke kerudung peneliti dan Widya meminta untuk menutup penitinya dan selesai memasangkan penitinya."'(25/10/2016)

Selanjutnya, Widya lebih sering menukar huruf ' $\mathrm{k}$ ' menjadi ' $\mathrm{t}$ ' karena mungkin dia sudah terbiasa menggunakan huruf ' $t$ '. Sebenarnya dia sudah mampu melafalkan huruf ' $\mathrm{k}$ ' namun belum sempurna jadi, dia lebih mudah melafalkan menggunakan huruf ' $t$ '. Contohnya pada kata 'aku' menjadi 'atu', 'iki' menjadi 'iti'.

\section{Perubahan huruf ' $c$ ' menjadi ' $t$ '}


"Guru : Video apa, dan salah satu temanya menjawab itu loh punya.e bunda Sofi video.e.

Widya : Video sen itu loh sen untune topot untune nang hp.

Guru : Gigi.e siapa yang copot?

Widya : Nenek.e.

Guru : Nenek.e siapa?

Widya : Hp,hp ne bunda

Sofi."'(25/10/2016)

Bunyi-bunyi konsonan yang lain sering muncul banyak yang diganti dengan konsonan lain dalam ucapannya. Seperti contoh di atas, konsonan 'c' pada kata copot diganti dengan konsonan ' $t$ ' menjadi topot. Demikian pula konsonan 's' pada kata samping diganti dengan konsonan ' $t$ ' menjadi tamping. Di samping konsonan-konsonan tersebut di atas, nampaknya pada umur 5 tahun seperti, umur Widya belum bisa mengungkapkan konsonan ' $r$ '. Ini nampak dengan adanya pergantian konsonan tersebut dengan konsonan-konsonan lain.

\section{Davin}

Dari segi fonologi, Davin yang berumur 4 tahun sudah mampu untuk berujar, namun ada beberapa huruf yang tak mampu untuk dilafalkannya. Contohnya seperti huruf k, g, r, dll. Kata-kata yang diucapkan oleh Davin terpengaruh dengan ucapan orang tua atau bahasa ibu yaitu bahasa kesehariannya saat di rumah. Karena, kata-kata yang diucapkan oleh Davin sangat sulit dimengerti oleh teman sebayanya maupun pendidiknya.

\section{Perubahan huruf ' $k$ ' menjadi} ' $t$ '

Berikut kutipan percakapan dengan Davin yang merubah huruf ' $k$ ' menjadi ' $t$ '.
Saat anak sedang bermain di ruangan kantor guru, lalu peneliti menanyakan kenapa tidak mau mengaji tadi, dengan percakapan seperti di bawah ini:

"Guru : Mas Davin tadi makan ikan apa?

Davin : Itan ayam.

Guru : Aku mainan,iya tah? Mau

mainan apa.

Davin : Nennenan leta-letaan.

Guru : Main kereta-keretaan

,dimana?

Davin : Di setolah.”(08/11/2016)

Davin lebih sering menukar huruf ' $k$ ' menjadi ' $\mathrm{t}$ ' karena mungkin dia sudah terbiasa menggunakan huruf ' $t$ '. Sebenarnya dia sudah mampu melafalkan huruf ' $k$ ' namun belum sempurna, jadi dia lebih mudah melafalkan menggunakan huruf ' $t$ '. Contohnya pada kata 'ikan' menjadi 'itan', 'sekolah' menjadi 'setolah', dan 'kereta' menjadi 'keleta'.

Jika ada pembiasaan dalam berbicara saat dirumah mungkin Davin bisa merubahnya, sebenarnya Davin adalah anak yang sangat pintar karena di usia 4 tahun dia sudah mampu berbicara dengan jelas dan runtut meskipun kata-kata yang diucapkan terlalu cepat dan pelat. Ia sudah mampu bercerita apa saja keseharian dia saat dirumah dengan runtut, tetapi kendalanya hanya saat dia berbicara dengan perkataan yang pelat.

\section{Perubahan huruf ' $g$ ' menjadi} 'd'

'Guru : Kenapa tadi kok waktu mengaji gak mau ngaji?

Davin : Dak mau, aku nennenan.(08/11/2016)

Guru bertanya kembali ke Davin, nanti kalau ketahuan mama makan donat dimarahi. 
Davin : Dak, dak, dak papa, huhuhhhh, mana unya

ku."(15/11/2016)

Begitu juga pada kata 'gak' menjadi 'dak', seperti yang terdapat pada kutipan percakapan di atas konsonan velar ' $g$ ' dan ' $d$ ' sebenarya Davin mampu mengucapkan huruf ' $g$ ' dengan jelas akan tetapi, pada saat huruf ' $\mathrm{g}$ ' digabung dengan huruf lain dan menjadi kata atau kalimat maka huruf ' $g$ ' tersebut hilang dan berubah bunyi menjadi huruf ' $d$ '.

Pada awal kata, konsonan ' $\mathrm{g}$ ' tidak terdengar seperti pada kata 'dak' (gak), tetapi pada tengah kata huruf ' $g$ ' terdengar seperti pada kata 'abis cuci angan' (habis cuci tangan) sementara itu konsonan ' $d$ ' sering sekali terdengar dalam pengucapan Davin. Misalnya pada kata ayo bunda, konsonan 'd' pada kata 'bunda'.

\section{Perubahan huruf ' $r$ ' menjadi ' $l$ '}

"Guru : Mau mainan yang mana?

Davin : Teleta api yang dua.

Guru : Yang apa?

Davin : Yang teleta api.

Guru : Berapa?

Davin : Satu.

Guru : Ini taruk atas apa taruk

bawah.

Davin : Ini ini ulsi.

Guru : Kursinya diturunkan, ini

sudah.(08/11/2016)

Guru : Di belikan siapa?

Davin : Olang yang anak.

Guru : Mama nya siapa?

Davin : Mama nya Alas.

Guru : Mama nya Farras tah?

Davin : Iyaa.

Guru : Tadi kamu bawa bekal apa?

Davin : Osis sama loti donat."(15/11/2016)

Bunyi-bunyi yang diucapkan oleh Davin sejak umur 4 tahun, akan dilihat sebagai bagian dari pemerolehan bahasa. Pada umur 4 tahun, Davin telah banyak memperoleh dan meproduksi berbagai fonem yang dapat membedakan arti kata-kata yang diucapkannya. Hanya saja dalam mengungkapkan kata-kata ini pada umur 4 tahun, kemampuan fonologi Davin baru pada bunyi-bunyi konsonan seperti /r/, /l/, pada kata 'kereta' menjadi 'teleta', 'kursi' menjadi 'ulsi', 'orang' menjadi 'olang', nama salah satu temannya 'Farras' menjadi alas dan 'roti' menjadi 'loti'.

Kata-kata ini sering sekali diucapkan oleh Davin. Kata-kata ini diucapkan dalam situasi di sekolah misalnya ketika di ajak berbicara. Fonem ' $r$ ' muncul sekali-sekali dan tidak sesering munculnva fonem ' 1 '. Ia tidak bisa melafalkan huruf ' $r$ ' karena artikulator aktif melakukan kontak beruntun dengan artikulator pasif, sehingga bunyi yang diucapkan menjadi berbeda.

\section{Farras}

Dari segi fonologi, Farras yang berumur 3 tahun, sudah mampu untuk berujar namun, ada beberapa huruf yang tak mampu untuk dilafalkannya. Contohnya seperti huruf r, g, dll. Kata-kata yang diucapkan oleh Farras terpengaruh dengan ucapan orang tua atau bahasa ibu yaitu bahasa kesehariannya saat di rumah. Karena, kata-kata yang diucapkan oleh Farras sangat sulit dimengerti oleh teman sebayanya maupun pendidiknya.

\section{Menciptakan kata-kata unik}

"Setelah Davin pulang tinggal Farras yang belum pulang dan saya tanyai, mas Farras ini loh tabungannya ketinggalan.

Farras : Ayas lupa. 
Guru : Mas Farras tadi makan ikan apa.

Farras : Dok ikin."(15/11/2016)

Selanjutnya, Farras sering menciptakan kata-kata kreasi yang orang lain belum mengerti, dan hanya orang-orang yang sudah dekat dengannya yang bisa mengerti apa yang hendak Farras katakan. Contohnya saat Farras mengatakan kata 'telur dadar' menjadi 'dok bikin', kata-kata tersebut sangat jarang digunakan oleh anak-anak yang usianya 3 tahun dan bahkan hanya Farras saja yang mengungkapkan kata-kata kreasi dan berbeda seperti itu.

Sebenarnya sang guru juga tidak mengerti apa kata-kata yang diucapkan oleh Farras, karena setiap kali ditanya tentang bawa bekal apa dia selalu berkata membawa dok bikin lalu peneliti menanyakan kepada mamanya, apa itu ma arti dok bikin. Dan mamanya menjawab iya bunda dok bikin itu telur dadar, di rumah sering minta telur dadar bun, dok bikin itu maksudnya telur diceplok 'dok' dalam bahasa jawa yang artinya 'telur', 'bikin' maksudnya yaitu membuat. Katakata tersebut sangat unik menurut peneliti dan hanya Farras saja yang mengungkapkan kata-kata seperti itu.

\section{Perubahan huruf ' $r$ ' menjadi ' $y$ '}

"Salah satu guru membawa minum dan berkata mau tah ini, apa seh ini.

Farras menjawab : Siyup.

Guru : Apa siyup? sirup tah.

Farras : Iya siyup."(15/11/2016)

Bunyi-bunyi yang diucapkan oleh Farras sejak umur 3 tahun akan dilihat sebagai bagian dari pemerolehan bahasa. Pada umur 3 tahun, Farras telah banyak memperoleh dan meproduksi berbagai fonem yang dapat membedakan arti kata-kata yang diucapkannya. Hanya saja dalam mengungkapkan kata-kata ini pada umur 3 tahun, kemampuan fonologi Farras baru pada bunyi-bunyi konsonan seperti /r/, /y/, pada kata 'sirup' menjadi 'siyup'.

Kata-kata ini sering sekali diucapkan oleh Farras. Kata-kata ini diucapkan dalam situasi di sekolah misalnya ketika peneliti mengajak berbicara. Fonem ' $r$ ' muncul sekalisekali dan tidak sesering munculnva fonem ' $y$ '. Ia tidak bisa melafalkan huruf ' $r$ ' karena artikulator aktif melakukan kontak beruntun dengan artikulator pasif, sehingga bunyi yang diucapkan menjadi berbeda.

3. Perubahan huruf ' $g$ ' menjadi 'd'

"Guru : Mau lagi.

Farras : Iya lagi lagi, dak dak hehe."'(15/11/2016)

Begitu juga pada kata 'gak' menjadi 'dak', seperti yang terdapat pada kutipan percakapan di atas konsonan velar ' $g$ ' dan 'd' sebenarya Farras mampu mengucapkan huruf ' $g$ ' dengan jelas akan tetapi, pada saat huruf ' $\mathrm{g}$ ' digabung dengan huruf lain dan menjadi kata atau kalimat maka huruf ' $g$ ' tersebut hilang dan berubah bunyi menjadi huruf ' $d$ '. Pada awal kata, konsonan ' $g$ ' tidak terdengar seperti pada kata 'dak' (gak).

\section{PEMBAHASAN}

Pada usia 3-6 tahun, perkembangan bahasa anak telah banyak memperoleh dan memproduksi berbagai fonem yang dapat membedakan arti kata-kata yang diucapkannya. Hanya saja dalam mengungkapkan kata-kata ini kemampuan fonologi Widya, Davin, 
dan Farras baru pada bunyi-bunyi konsonan seperti huruf ' $\mathrm{g}, \mathrm{r}, \mathrm{k}$, c, s. Pada kata 'lek' 'rek' dalam bahasa jawa 'sayulan' (sayuran) , 'aku' menjadi 'atu', 'gak' menjadi 'dak', dll. Kata-kata ini sering sekali diucapkan oleh Widya, Davin, dan Farras karena, adanya pembiasaan berbicara seperti itu yang selalu ditanamkan oleh orang tua, yaitu dengan berbicara pelat dan tidak membenarkan kesalahan bahasa mereka, malah menggunakan bahasa seperti itu dalam kehidupan sehariharinya.

\section{SIMPULAN}

Berdasarkan hasil penelitian, dapat disimpulkan bahwa bahasa anak sangat dipengaruhi oleh bahasa orang tuanya, anak terbiasa berkata pelat dan menciptakan kata-kata kreasi akibat adanya pembiasaan yang diucapkan oleh para anggota keluarganya. Menurut para orang tua berkata pelat kepada anaknya adalah wujud kasih sayang orang tua yang selalu berkata dengan menirukan kata-kata pelat anaknya tersebut, tetapi itu adalah hal yang salah karena sang anak akan terbiasa menggunakan kata-kata pelat tersebut.

Huruf yang belum mampu untuk dilafalkan jika dirangkai menjadi kata atau kalimat oleh ketiga anak tersebut rata-rata hurufnya sama, yaitu huruf 'r, g, dan k'.

Sebenarya, mereka mampu mengucapkan huruf-huruf tersebut dengan jelas pada saat disuruh untuk mengucapkan huruf itu tetapi, pada saat huruf-huruf tersebut digabung dengan huruf lain dan menjadi kata atau kalimat maka huruf-huruf tersebut hilang dan berubah bunyinya.

\section{SARAN}

Berdasarkan hasil penelitian, saran yang perlu diperhatikan adalah:

1. Bagi pembaca dapat menambah wawasan dan pengalaman langsung tentang bahasa anak usia dini yang unik.

2. Untuk peneliti lain dapat dijadikan acuan dalam menganalisis fonologi atau bentuk ujaran seseorang.

3. Untuk orang tua agar mengetahui penggunaan bahasa yang baik dan benar saat berbicara kepada anak agar tidak terjadi kesalahan dalam berbicara.

\section{DAFTAR PUSTAKA}

Chaer, Abdul. 2003. Linguistik Umum. Jakarta: Rineka Cipta.

Chaer, Abdul. 2009. Fonologi Bahasa Indonesia. Jakarta: Rineka Cipta.

Dhineni Nurbiana. Metode Pengembangan Bahasa: Universitas Terbuka.

Djajasudarma, T. Fatimah. 2006. Metode Linguistik: Ancangan Metode Penelitian dan Kajian. Bandung: Refika Aditama.

Moleong, J. Lexy. 2002. Metodologi Penelitian Kualitatif. Bandung: Remaja Rosdakarya.

Santrock, J. W. (2007). Perkembangan Anak (Mila rahmawati, Anna Kuswanti. Terjemahan). Jakarta: Erlangga.

Slamet Suyanto. (2005). Dasardasar Pendidikan Anak Usia Dini. Yogyakarta: Hikayat Publishing.

Sudaryanto. 2015. Metode dan Aneka Teknik Analisis Bahasa. Yogyakarta: Sanata Dharma University Press. 